Journal of Teacher Education for Sustainability, vol. 19, no. 2, pp. 138-153, 2017

\title{
Gender Identity of Students and Teachers: Implications for a Sustainable Future
}

\author{
Jeḷena Badjanova, Anita Pipere and Dzintra Iliško \\ Daugavpils University, Latvia
}

\begin{abstract}
Considering the gender identity as a crucial aspect of the culture that shapes our daily life and recognising the research gap on this topic in the context of sustainable education, the paper describes the quantitative cross-sectional study on gender identity of students and teachers comparing the respondents by their age and sex. Three age groups (106 female and 62 male) participated in the study: 18-19-years-old pupils from comprehensive and vocational schools $(\mathrm{n}=59), 20-15$-years-old university students $(\mathrm{n}=52)$ and 24-64years-old teachers working at respective schools and universities $(n=57)$. The original Bem Sex Role Inventory was administered to measure the individual gender identity types of masculinity, femininity, and androgyny. The majority of respondents from all age and sex groups described themselves as androgynous. Male and university students featured the scattering of scores more toward masculinity, while the scores of female, pupils, and teachers were more inclined toward femininity. No statistically significant differences were found among the three age groups, while sex appeared to be more influential factor causing significant differences between male and female in terms of gender identity with male's inclination toward masculinity and female's inclination toward femininity. Dominance of androgynous individuals challenges the current approaches to the gender education in the context of sustainable development.
\end{abstract}

Keywords: gender identity, androgyny, masculinity, femininity, education for sustainable development

Today it becomes self-evident that gender identities and gender relations are significantly connected with the cultural progress since they determine the daily life of each person, family, workplace, and wider community. At the same time, global changes, especially social and economic turbulences push the cultural values toward modification and variations, different interests intervening this process (Schalkwyk, 2000). In this paper we suggest the possibility of creative adaptation of gender analysis, advocated for over 20 years, to the educational issues related to sustainability. Gender stands for the socially determined difference of cultural norms and expectations linked to the biological differences between the sexes. These social constructions of gender vary in time and place and between the cultures (European Commission 2009, part 1.2.). 


\section{Gender Analysis: Imperative for Sustainability Issues and ESD}

In a traditional sense, the gender analysis could be explained as the process implemented during the program and project design "assessing the impact that a development activity may have on females and males, and on gender relations (the economic and social relationships between males and females which are constructed and reinforced by social institutions). It can be used to ensure that men and women are not disadvantaged by development activities, to enhance the sustainability and effectiveness of activities, or to identify priority areas for action to promote equality between women and men" (Hunt, 2004). The aim of gender analysis is to increase the quality and effectiveness of initiatives as well as to redress inequalities and inequities (Badjanova \& Iliško, 2015; Badjanova, Raščevskis, \& Iliško, 2017).

Considering education as a part of the culture and conceiving education for sustainable development (ESD) as some global educational project, it is obvious that both ESD and teacher education (TE) for sustainable development (SD) should also be based on gender analysis. A gender analysis, therefore, should provide information and inquiry about the social groups that would be affected by an initiative (namely, ESD and TE for SD) - about their gender differences, gender identities, relationships, etc. In the presented paper we intend to shed some light on the gender identity of pupils, students and teachers both at comprehensive schools and university as they all should potentially be involved in the global processes of educational paradigm shift towards sustainability (Pipere, 2016; Salite, 2015). The literature search shows the gap in the research on ESD in terms of gender issues, albeit, the disregard of this aspect of culture would possibly lead to unwanted consequences.

A clear global mandate was imposed on ESD and HESD to integrate gender in all activities by the Bonn Declaration: "ESD should actively promote gender equality, as well as create conditions and strategies that enable woman to share knowledge and experience about social change and human well-being” (UNESCO 2009, paragraph $15 \mathrm{~m})$. So far the major focus of gender analysis in terms of ESD has been related to gender equality focus on women and girls only. In this paper we will try to develop the deeper understanding regarding the gender identity, much less investigated topic in the field of sustainability.

\section{Gender Differences in Environmentalism and Sustainability}

As a majority of studies have shown, women display stronger environmental attitudes and behavior than men (Heinzle, Kanzig, Nentwich, \& Offenberger, 2010; Hunter, Hatch, \& Johnson, 2004; Vinz, 2009; Xiao \& Hong, 2010; Zelezny, Chua, \& Aldrich, 2000). However, few studies have shown no differences or even stronger engagement in environmental behavior by men (Eisler, Eisler, \& Yoshida, 2003). The theory on gender roles and socialization (Howard \& Hollander, 1996; Unger \& Crawford, 1996; Wilkinson \& Kitzinger, 1996) suggests that individuals in their social role of gender are molded by expectations provided by cultural norms. Females across cultures are socialized to be more expressive, caring, interdependent, compassionate, nurturing, cooperative, and helpful in caregiving roles (Beutel \& Marini, 1995; Chodorow, 1974; Eagly, 1987; Gilligan, 1982), while males are socialized to be more independent and competitive (Chodorow, 1974; Gilligan, 1982; Keller, 1985). In the study by Zelezny, Chua, and Aldrich (2000), females, regardless of age (i.e., youth or adult), reported more concern for the 
environment and pro-environmental behaviour than males. Recent studies also show the gender gap between boys and girls, girls having stronger sustainability consciousness; this gap is increasing from 12 to 19 years of age and amplified in ESD-oriented schools (Olsson \& Gericke, 2017). In this light, one of the Sustainable Development Goals (UNESCO, 2015) to achieve gender equality and empower all women and girls sounds hardly relevant at least for developed European countries, where, on the contrary, boys should be empowered more as to reach the gender balance in sustainability issues.

On the other hand, gender norms, identified as the social prescriptions of gender roles both in terms of masculinity and femininity, have been indicated as being in tension with the foundations of SD (Blake, 2006; Eisler, 1994; Franz-Balsen, 2014; Rogers, 2008). Traditional gender norms of masculinity, prioritizing domination, competitiveness and short term success on the individual or corporate scale or the so called "hegemonic masculinity" (Connell, 1995) oppose many documents containing guidelines for SD, for instance, Earth Charter (The Earth Charter Commission, 2000) and conflict with ethical, ecological and social implications of SD. The norms of femininity contradict with empowerment and participation of women in social activities for SD, however, some authors point to the "feminization of environmental responsibility" (Schultz \& Stiess, 2009), since the woman have experience in social change and improvement of human well-being. According to Franz-Balsen (2014, p. 1981), "the social construct of hegemonic masculinity affects men most by the expectations they have to meet, but it is not tied to a male body: women may internalize the masculine norm of competitiveness and dominance just as well, because it is key for success in the workplace or in politics. In addition, as mothers educating a son to become a real boy/man, or as teachers, women may use the symbols and myths around hegemonic masculinity, thus "doing gender" ". Therefore, we should ask, if the problem takes its roots in gender per se or in internalized norms carried both by female and male today in order to survive and reach their goals.

\section{Gender Identity: Interdisciplinary View}

Gender identity refers to the degree to which a person perceives the self to be masculine or feminine, considering the meaning of masculine or feminine in a given culture (Perry \& Pauletti, 2011; Stets \& Burke, 2000; Tobin et al., 2010; Wood \& Eagly, 2009). Societal norms of ideal masculine and feminine person may inform our gender identity, when we compare our features with those from a gender category. Gender identity can justify the specific gendered behaviour in the social sphere (Tobin et al., 2010; West \& Zimmerman, 1987). Therefore, gender identity influences how people perceive the world around them and how they behave (Vantieghem, Vermeersch, \& Van Houtte, 2014). Gender identity evolves since early age due to cognitive and categorical processing through the lifetime. According to the social-cognitive gender schema theory, children develop their own ideas on the meaning of masculinity or femininity (i.e., gender schemas) very early and use these ideas to process information, in decisionmaking and in order to regulate their behavior (Starr \& Zurbriggen, 2017).

The research on masculinity and femininity shows both the periods of agreement on theory and methodology and times of hot discussions and friction. From the end of the 1990's the scholars have come to the agreement on multidimensional and multifactorial understanding of masculinity-femininity showing that overarching masculinityfemininity (gender identity) construct consists of the scores in different areas of human 
life, like interests, attitudes, traits, appearance, behavior, etc. However, these areas do not show high correlation among themselves and correlations may vary on the individual level (Perry \& Pauletti, 2011; Spence, 1993; 1999).

\section{Androgyny: Concept and Contemporary Implications for Sustainability and Education}

According to Ivtzan and Conneely (2009), a major distinction between physical differences of men and women are highlighted in all trait theories like Parson and Bales' (1955) Instrumental and Expressive dimensions, Guttmann's (1965) Impersonal and Personal orientations or Bakan's (1966) modalities of Agency and Communion. At last, in 1973, Block advanced the theoretical idea of gender identity secure enough to express both Agency (masculine personality) and Communion (feminine personality), thus incorporating both male and female features. Such a role would be beneficial in two opposing situations, ensuring larger repertoire of behaviour and, therefore, larger social success. Following Block, the construct of androgyny was first fully formulated by Sandra Bem $(1974,1975)$ arguing that masculinity and femininity represent independent clusters of socially desirable instrumental and expressive traits. Thus, the psychologically androgynous person possesses similar levels of feminine and masculine traits (Ivtzan \& Conneely, 2009). Tests measuring androgyny provide two separate scales for Masculinity (including assertiveness, independence, etc.) and Femininity (including sensitivity, kindness, empathy, etc.) (Bem, 1974; Spence, Helmreich, \& Stapp, 1975).

Psychological androgyny is linked with several important positive phenomena like psychological well-being, self-esteem, satisfaction with life, marital satisfaction (e.g., Baucom \& Aiken, 1984), ego identity, parental effectiveness, perceived competence, achievement motivation, cognitive complexity when evaluating careers, creativity (e.g., Norlander, Erixon, \& Archer, 2000), and behavioural flexibility (e.g., Bem \& Lewis, 1975). Some of these phenomena, especially self-esteem, perceived competence, cognitive complexity, creativity and behavioural flexibility could be positively related to sustainability consciousness and behavior. The androgyny has also been linked with effective leadership as more integrative and flexible, and more appropriate for achieving high performance in today's complex organizations (Kark, 2017). The fact that androgynous leaders were perceived by employees as better leaders and as ones that they identify with to a greater extent (Kark, Waismel-Manor, \& Shamir, 2012) would also be extended to the context of education where school and university teachers would, possibly, be more or less deliberately assumed as the androgynous identity as to be more effective leaders for learning process and role models for their students.

However, considering the above-mentioned cultural and social context of views on masculinity and femininity, studies on gender identity should be based on measures relevant for given culture or subculture and renewed following changes in gender stereotypes with time in specific culture. The latest developments in this field of study suggest the discussion on individuals with instrumental and expressive traits instead of stereotypical masculine and feminine labels (Kark, 2017). For instance, in the 1970's, the sample studied in the US by Bem contained only $21 \%$ of androgynous male and $29 \%$ of androgynous female students, which is quite natural considering gender role models popularized by society at this time. It would be interesting to explore the prevalence of androgynous individuals in the present time European society. 


\section{Research on Androgyny: Impact of Age, Gender and Educational Context}

Regarding the age differences in terms of androgyny, middle-aged adults are more likely to be classified as androgynous (Fischer \& Narus, 1981). Also some life-span gender differences in androgyny have been found, showing that men become more androgynous moving from young age to middle age and later periods of life (Hyde \& Phillis, 1979; Hyde, Krajnik, \& Skuldt-Niederberger, 1991). For women, the age pattern is not so clear, however, more recent study implicates that women also become more androgynous with age (Kasen, Chen, Sneed, Crawford, \& Cohen, 2006). Small effect sizes when androgyny of men and women at similar age are compared suggest that men and women are more similar than they are different (Hyde, 2005; Strough, Leszczynski, Neely, Flinn, \& Margrett, 2007) and, therefore, their engagement with environmentalism and sustainability further would be based on larger similarity and overlapping of traits than it was theoretized before. Strough with colleagues (2007) encourage the exploration of gender identity in various age periods to see the impact of historical events on the interpretation of obtained results.

Analysing the androgyny in social context of educational institutions, it becomes clear that today such context is especially favourable for this type of gender identity. For instance, two recent studies in China's universities have shown that the number of androgynous and undifferentiated students was much higher than the number of masculine or feminine students (Cai, Huang, \& Song, 2008; Huang, Zhu, Zheng, \& Zhan, 2012). According to Twenge (1997), college-age women's masculine trait scores increased from 1975 to 1995 , while men's masculinity remained the same; he also revealed few cohort differences in men's femininity over time. This was explained with social changes in women's workforce participation as well as with shift in woman's social roles in general (Eagly, 1987; Wood \& Eagly, 2002). Androgynous gender role now is desirable in educators (Eichinger, Heifefetz, \& Ingraham, 1991), stereotypes portrayed leaders as less masculine in educational organizations than in other domains (Koenig, Eagly, Mitchell, \& Ristikari, 2011). Furthermore, according to Schwendenman (2012), "high achievement [at school] seems to be related to androgyny, a socially and psychologically healthy basis for human interactions, but a feminine role is perceived as counter to academic achievement, a finding parallel to the results of 1980".

\section{Measuring Gender Identity}

The Bem Sex Role Inventory (BSRI) is the most well-known and validated gender identity measure used to study androgyny (Ivtzan \& Conneely, 2009). It was created echoing the developments of women's movement of the 1970s (Bem, 1974) "to measure the extent to which a person divorces himself from those characteristics that might be considered appropriate for the opposite sex" (p. 156). The BSRI assumes that qualities desirable for each sex differ in the U.S. culture, while people differ in the extent to which they follow these social standards (Bem, 1979). Initial research by this measure classified respondents into categories based on their scores on the masculine and feminine dimensions, yielding four groups of individuals: (a) masculine sex-typed, scoring high on masculinity and low on femininity, (b) feminine sex-typed, scoring high on femininity and low on masculinity, (c) androgynous, scoring high on both masculinity and femininity, and (d) undifferentiated scoring low on both masculinity and femininity (Wood \& Eagly, 2015). 
However, this measure has also been criticised regarding both its theoretical framework, research questions studied and proper usage of method by researchers. Hoffman and Borders (2001) suggest that in their own study college students perceived BSRI items very differently from the gender-stereotypical way applied by the 1970s college students who were judges during the test development. Similar to other scales (e.g., Personal Attributes Questionnaire, PAQ, by Spence et al., 1975), the BSRI appears to draw from more specific constructs like already mentioned instrumentality/agency and expressivity/communion (e.g., Abele \& Wojciszke, 2007; Fiske, Cuddy, Glick, \& Xu, 2002), rather than masculinity and femininity in general.

\section{Method}

This quantitative cross-sectional study aims at exploring the gender identity of pupils, students and teachers comparing the respondents by their age and sex. The authors are interested in the degree of androgyny in the given sample of Latvian inhabitants in the cultural and social landscape of the $21^{\text {st }}$ century in general as well as considering different age groups and sex of participants closely linked with educational context and, therefore, unavoidably engaged with (or disengaged from) sustainability discourse. The following research questions were set: 1) What differences in gender identity exist among the three age groups (adolescents, early adulthood and adulthood)? 2) What differences in gender identity exist among the women and men in the studied sample?

\section{Participants}

Three age groups (106 women and 62 men) were selected according to the three stages of psychosocial development by E. Erikson (1982): adolescence, early adulthood and adulthood. Convenience sample of inhabitants from different regions of Latvia included 18-19-years-old ( $\mathrm{M}=18.2, \mathrm{SD}=0.42)$ pupils from comprehensive and vocational schools ( $\mathrm{n}=59 ; 61 \%$ women/37\% men)), 20-25-years-old $(\mathrm{M}=21.9, \mathrm{SD}=1.60)$ university students ( $\mathrm{n}=52 ; 56 \%$ women $/ 44 \%$ men $)$ ) and 26-64-years-old $(\mathrm{M}=37.6, \mathrm{SD}=10.2)$ teachers working at respective schools and universities ( $n=57 ; 41 \%$ women $/ 16 \%$ men).

The data was collected in the 2016-2017, mostly recruiting the groups of participants in their places of study or work. The survey data was also obtained by e-mails contacting participants from distant regions of Latvia. The data collection was conducted by the main author of the paper as well as by properly trained research assistants. The informed consent from all participants was acquired before the administration of the survey, ensuring the consideration of confidentiality and anonymity regarding the received data.

\section{Measure and Data Analysis}

The original Bem Sex Role Inventory (BSRI, Bem, 1974) was administered to measure the individual gender identity types of masculinity, femininity, and androgyny. The measure consists of a list of 60 attributes and behaviours; 20 of which were verified to be more socially desirable when demonstrated by men (e.g., competitive, aggressive), 
20 deemed more appropriate for women (e.g., understanding, compassionate, tender), and 20 of no-gender affiliation or neutral (e.g., friendly, conscientious). These traits were presented to the participants in a systemised order, however, to prevent order or fatigue effects on overall Masculinity or Femininity scores, and dissueade them from recognizing the true purpose of the measurement. Participants rated each attribute by the way they perceived each according to a five-point Likert scale running from one (Strongly Disagree) to five (Strongly Agree). Thus, the BSRI was completed by simply writing a number from one to five next to all 60 words.

Bem's (1974) reported test-retest reliability was .90 for masculinity and femininity and 0.93 for androgyny. The BSRI manual (Bem, 1981) reports that original tests in the US resulted in internal consistencies that ranged from 0.80 to 0.86 . In this study, the internal consistency coefficient of the masculinity scale was 0.78 , and the internal consistency coefficient of the femininity scale was 0.74 .

The data was analysed initially obtaining the sum of 20 respective femininity items (F) and the sum of 20 respective masculinity items (M) for each respondent. Afterwards, the index of sex-type (IS, namely, gender identity type - further used interchangebly) was calculated using the formula (F-M) X 2.322 (Bem, 1974). Masculinity was identified if IS $<-1$, femininity was identified if IS $>+1$; IS $>+2.025$ denotes the pronounced femininity, while IS $<-2.025$ designates the pronounced masculinity. IS within the range from -1 to +1 designates the androgyny (Беспанская-Павленко, 2013).

The data further was analysed using the descriptive statistics, one-way ANOVA and t-test for independent samples.

\section{Results}

\section{Gender Identity in Sample Groups}

Out of all 168 respondents, only 10 (5.9\%) described themselves as masculine, 11 $(6.5 \%)$ as feminine, other $147(87.5 \%)$ reported their gender identity as androgynous. More detailed overview featuring the distribution of different types of gender identity for various age and sex groups is presented in Table 1.

Table 1

Distribution of Gender Identity Types in Age and Sex Groups of Sample (N=168)

\begin{tabular}{lcccc}
\hline $\begin{array}{c}\text { Gender } \\
\text { identity type }\end{array}$ & $\begin{array}{c}\text { Pupils } \\
(18-19 \text { year olds }) \\
(\mathrm{n}=59)\end{array}$ & $\begin{array}{c}\text { Students } \\
(20-25 \text { year olds }) \\
(\mathrm{n}=52)\end{array}$ & $\begin{array}{c}\text { Teachers } \\
(26-64 \text { year olds }) \\
(\mathrm{n}=57)\end{array}$ & $\begin{array}{c}\text { Sample } \\
\text { (in total) }\end{array}$ \\
\hline Masculinity & 0 & Women $(\mathrm{n}=106)$ & 1 & 1 \\
\hline Feminity & 5 & 0 & 4 & 94 \\
\hline Androgyny & 31 & 2 & 36 & 9 \\
\hline Masculinity & 3 & Men $(\mathrm{n}=62)$ & 1 & 0 \\
\hline Feminity & 0 & 5 & 0 & 53 \\
\hline Androgyny & 20 & 0 & 15 & \\
\hline
\end{tabular}


As it is shown in Table 1, all age and sex groups of our sample consist predominantly of persons reporting themselves as androgynous according to BSRI. Among the oldest group of women, one participant described herself as having mostly masculine characteristics, while none of men has depicted himself through the femininity gender identity type.

\section{Gender Identity Differences by Age Groups}

Table 2 depicts the mean and standard deviation of sex-type index obtained through the formula mentioned above as well as the range of this index for different age groups.

Table 2

Sex-type Index for Different Age Groups of Sample (N=168)

\begin{tabular}{ccccc}
\hline Age & N & M & SD & Range of sex-type index \\
\hline $18-19$ year olds & 59 & 0.11 & 0.654 & From -1.16 to +1.63 \\
\hline $20-25$ year olds & 52 & 0.02 & 0.619 & From -1.39 to +1.16 \\
\hline $26-64$ year olds & 57 & 0.14 & 0.577 & From -1.16 to +1.63 \\
\hline
\end{tabular}

According to Table 2, the findings from 18-19-years-old pupils from comprehensive and professional schools show that their results fall into the range of scores designating the androgyny with scaterring toward femininity. Interestingly, almost the same level of androgyny with scaterring toward femininity has also been found in the oldest age group (26-64-years-old) comprising school and university teachers. Androgyny was self-reported also by 20-25-years-old university students, though in this case the scores were scaterring towards masculinity.

Figure 1 features the boxplots showing the differences of three age groups in terms of their sex-type (androgyny) index. The boxplots display the full range of variation, the likely range of variation, median and outliers of obtained scores.

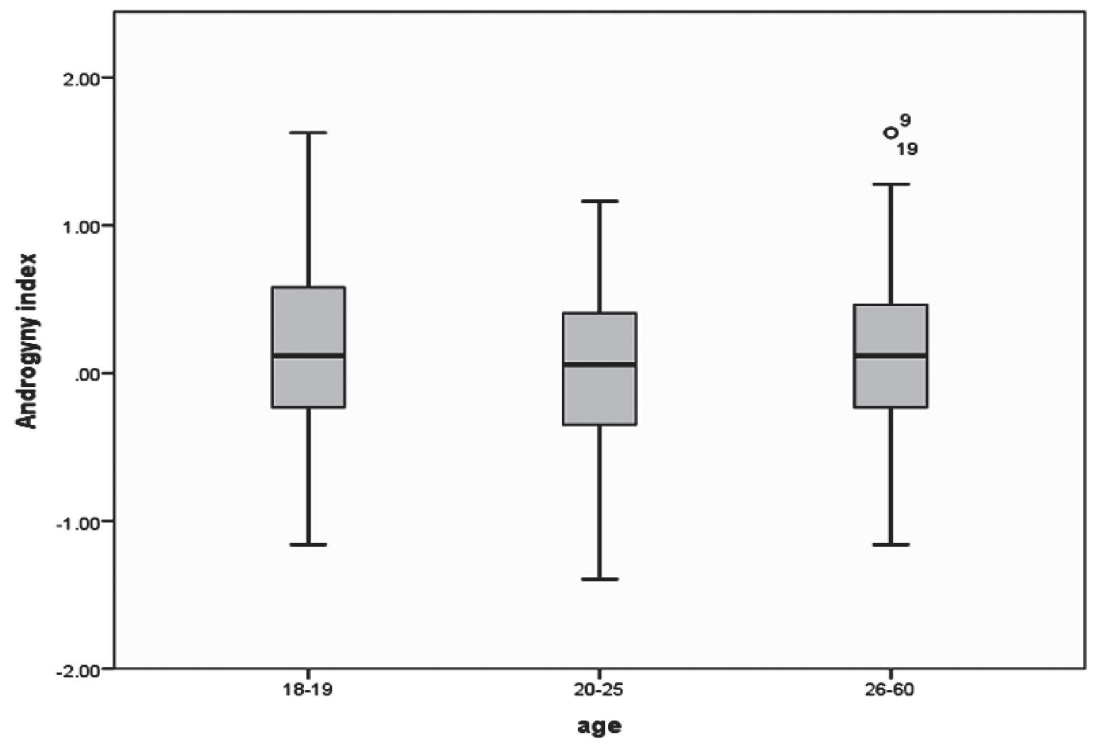

Figure 1. Distribution of sex-type index by age $(\mathrm{N}=168)$ 
A one-way ANOVA was conducted to compare effect of belonging to specific age group on the sex-type index. The analysis of variance showed that the effect of age group was not significant, $\mathrm{F}(2,165)=0.62, \mathrm{p}=0.541$. Therefore, it could be concluded that no statistically significant differences exist between three age groups (pupils, students and teachers) in terms of their sex-type index.

\section{Gender Identity Differences by Sex}

Table 3 depicts the mean, standard deviation, as well as the range of sex-type index obtained through the formula mentioned above regarding men and women of the given sample.

Table 3

Sex-type Index for Different Sex Groups of Sample (N=168)

\begin{tabular}{lcccc}
\hline \multicolumn{1}{r}{ Age } & $\mathrm{N}$ & $\mathrm{M}$ & SD & Range of sex-type index \\
\hline Men & 62 & -0.25 & 0.556 & From -1.39 to +0.81 \\
\hline Women & 106 & 0.30 & 0.561 & From -1.16 to +1.63 \\
\hline
\end{tabular}

According to Table 3, the findings for the sample group of men show that their results fall into the range of scores indicating the androgyny with scaterring toward masculinity. Higher scores of sex-type index, also in the range of androgyny, are featured by women whose answers reveal the scaterring towards femininity.

Figure 2 provides the boxplots featuring the differences between men and women in terms of sex-type (androgyny) index. The boxplots show the full range of variation, the likely range of variation and median of obtained scores.

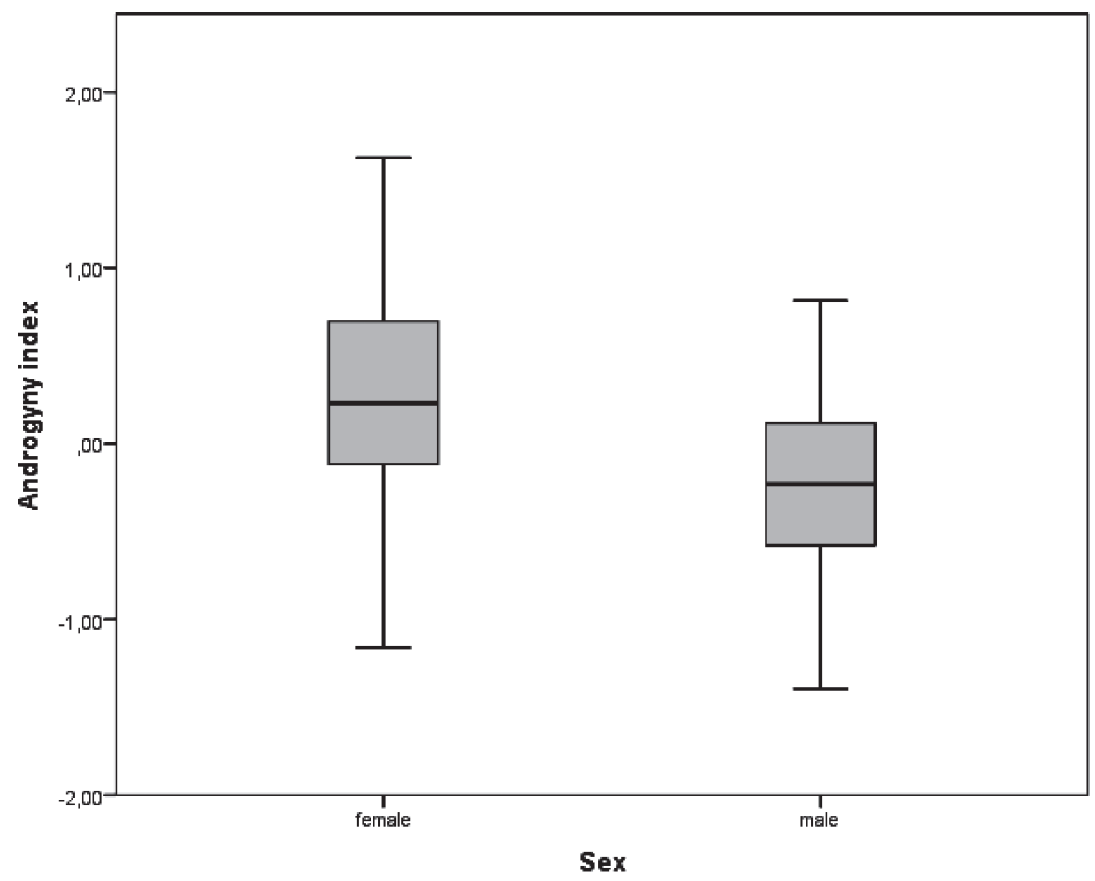

Figure 2. Distribution of sex-type index by sex $(\mathrm{N}=168)$ 
An independent-samples t-test was conducted to compare sex-type index for men and women in the given sample. There was a significant difference in the scores for men $(\mathrm{M}=-0.25, \mathrm{SD}=0.556)$ and women $(\mathrm{M}=0.30, \mathrm{SD}=0.561) ; \mathrm{t}(166)=6.09, \mathrm{p}=0.00$.

\section{Discussion and Conclusions}

The authors aimed to explore the gender identity of students and teachers by comparing the respondents by their age and sex, determining the prevalence of androgyny in the given sample of Latvian inhabitants in general as well as considering different age groups and sex of participants. In general, all age and sex groups in their majority contained individuals describing their gender identity as androgynous. Though, some groups featured the scattering of scores more toward masculinity (male, 20-25-years-old university students), while the scores of other groups were scattered more toward femininity (female, 18-19-years-old pupils, 26-64-years-old school and university teachers). No statistically significant differences were found among the three age groups in terms of androgyny, though, sex appeared to a more influential factor causing statistically significant differences between men and women in our sample (including people with a wide range of age). Both sex groups were found to be androgynous, though their mean scores were statistically different with male's inclination toward masculinity and female's inclination toward femininity.

Thus, our sample consists of respondents describing themselves predominantly as androgynous persons which is strikingly different from the initial findings by Bem in her sample of US students in the 1970's, but which is quite natural in the current cultural and social situation of European country at the beginning of the 21th century considering the social changes in society. Also, one should account for the social role of research participants, as the previous research shows that both the role of student and teacher ask for androgyny in order to succeed in these roles and to cope with high demands placed by current social, economical and cultural situation in Latvia (Eichinger, Heifefetz, \& Ingraham, 1991; Koenig, Eagly, Mitchell, \& Ristikari, 2011; Schwendenman, 2012).

According to Strough and colleagues (2007), the systematic interpretation of agerelated differences in gender identity has not yet emerged in research literature, since the researchers seldom include several age groups from adolescence through later adulthood in one study. The presented study, therefore, makes some steps in this direction, although the respondents are representatives of one peculiar context of education and the age group of later adulthood is not included. Regarding the differences in terms of androgyny among the three age groups - in adolescence, early adulthood and adulthood, it should be noticed that although all age groups display the androgyny as their gender identity, the lack of statistically significant differences shows that age in this peculiar sample could not be viewed as an important variable causing variations in gender identity. However, if in the youngest group of adolescents who are pupils at comprehensive and vocational schools and in the oldest group of adults (teachers from schools and universities) the scores of androgyny scaterred toward femininity, the middle age group of university students (early adulthood) was discovered as having scores scaterring toward masculinity. This could be partly explained with the gender distribution within these age groups, since the students' group included a larger proportion of men in comparison with other age groups. The obtained results seem to be in discord with the earlier study 
showing a higher level of androgyny in middle-aged adults in comparison with younger individuals (Fischer \& Narus, 1981) and also with more recent studies reporting that both men and women become more androgynous with age (Hyde \& Phillis, 1979; Hyde, Krajnik, \& Skuldt-Niederberger, 1991; Kasen, Chen, Sneed, Crawford, \& Cohen, 2006). It is clear, though, that this is not the linear development and growth of androgyny with age is also influenced by other important variables as gender, social status, professional affiliation, etc.

Besides, it has been found that gender identity can change in response to immediate contextual demands (Leszczynski \& Strough, 2007; Pickard \& Strough, 2003), we could suggest that scaterring towards masculinity or feminity in different social situations could change in line with the demands from environment. Possibly, in the highly competitive and demanding environment encountered during the studies at university, some students could choose the active coping style striving towards a more aggressive, dominating and independent behavior, since after leaving their family and school behind, they are entering new life, usually left on their own to survive in this new academic and social milieu (see Brougham, Zail, Mendoza, \& Miller, 2009).

However, the statistically significant differences in androgyny between male and female were found in the studied sample. However, the scores of both sexes fell into the range of androgyny, the group of men described itself as more masculine or more instrumental in their behaviour, while the group of women - as more feminine or expressive in terms of BSRI items.

This finding could be explained by the peculiar context of the study, namely, educational discourse as already mentioned above. In this discourse both male and female in their professional roles have been demanded to be, on the one hand, competitive, independent, assertive, on the other hand, understanding, compassionate, tender, etc. Besides, Lahelma (2000) has found that pupils overwhelmingly rejected gender as a salient factor in teacher-pupil relations, and tended to stress instead that individual teaching ability has the greatest impact. Notwithstanding, the gender stereotypes are still strong in Latvia picturing women as caring housewifes and men as emotionally distant breadwinners (ESF, 2017).

Several practical implications point to the links between obtained results and ESD. Dominance of androgynous individuals in different age and sex groups deeply engaged with educational discourse challenges the current approaches to the gender education in the context of SD. Androgyny of students and teachers shows that, in general, gender stereotypes might not be considered as factors inhibiting implementation of ESD in educational discourse, though, further research is needed to be sure if the same could apply with the sustainability communication in a wider community of Latvia. In the studied sample independence and assertiveness have been well balanced with empathy, patience and tenderness, therefore, at least in the given sample one should not encounter issues hindering sustainability-related life style.

Furthemore, the fact that androgyny is featured both by pupils and school teachers as well as by students and their university teachers seems to be potentially ruling out the possibility of conflicts when, for instance, instrumentally-oriented university teacher is trying to indoctrinate his or her cultural norms and worldviews to expressively-oriented student. Therefore, just performed gender exploration gives the possibility to build the gender education onto androgynous orientation, in order to analyse the specific contribution of each individual to sustainability irrespective of his or her gender identity. 
According to Franz-Balzen (2014), gender competence is necessary both for teachers and any other participants working in the field of sustainability communication. We can not deny that gender norms and identity are among the key elements of SD, since “they do not only influence people's worldviews and direct their behaviors, they also shape the organizational structures of societies and contribute to unjustifiable hierarchies and exploitation of resources all over the world" (p. 1987).

Regarding the limitations of this study, at first, we should indicate that this study used the popular measure (BSRI) to evaluate the research participants' identification with masculine, feminine and neutral traits in order to obtain the index of sex-type. Albeit this measure is commonly used to explore the gender identity, warnings regarding the construct validity of this measure should be considered when reflecting on the research outcomes. Also, to some degree the social desirability would have the certain impact on the results of this study, since students and teachers are social groups used to be assessed quite often and, probably, already have elaborated some coping mechanisms when dealing with negative self-perception caused by external evaluation. Finally, it should be noted that in the cross-sectional design of our study, age and gender are confounded and we did not attempt to distinguish group differences due to age from those due to gender.

In future it would be interesting to extend this study and explore the correspondence between the gender identity of the same age groups and social status from one side and their sustainability-related attitudes and self-reported behavior from the other side. Also, the mixed design studies, initially measuring the gender identity and then obtaining qualitative data from representatives of different types of gender identity regarding their experience of ESD as students and teachers could provide some understanding on relationships between gender norms and possibilities of ESD.

At the end we can conclude that the strong prevalence of androgynous individuals in our sample of students and teachers from comprehensive schools and universities representing different age and sex is a good news for those striving to shape all facets of educational system in Latvia in line with the principles and guidelines of ESD. At the same time, the study shows that some diversity and reasonable differences still exist between the gender identity of men and women in these age groups, so designating the peculiarities of gender roles so necessary for balanced, healthy and sustainable society.

\section{References}

Abele, A. E., \& Wojciszke, B. (2007). Agency and communion from the perspective of self versus others. Journal of Personality and Social Psychology, 93, 751-763.

Badjanova, J., \& Iliško, Dz. (2015). Holistic approach as viewed by the basic school teachers in Latvia. Discourse and Communication for Sustainable Education, 6, 132-140.

Badjanova, J., Raščevskis, V., \& Iliško, Dz. (2017). Gender differences of Latvian males and females at the stage of adulthood. Journal of Management and Marketing Review, 2(3), 38-43.

Bakan, D. (1966). The duality of human existence. Chicago: Rand McNally.

Baucom, D. H., \& Aiken, P. A. (1984). Sex role identity, marital satisfaction, and response to behavioral marital therapy. Journal of Consulting and Clinical Psychology, $52(3), 438-444$. 
Bem, S. L. (1974). The measurement of psychological androgyny. Journal of Consulting and Clinical Psychology, 42, 155-162.

Bem, S. L. (1975). Sex role adaptability: One consequence of psychological androgyny. Journal of Personality and Social Psychology, 31, 634-643.

Bem, S. L. (1979). Theory and measurement of androgyny: A reply to the PedhazurTetenbaum and Locksley-Colten Critiques. Journal of Personality and Social Psychology, 37, 1047-1054.

Bem, S. L. (1981). Bem Sex Role Inventory manual. Palo Alto, CA: Consulting Psychologists.

Bem, S. L., \& Lewis, S. A. (1975). Sex role adaptability: One consequence of psychological androgyny. Journal of Personality and Social Psychology, 31(4), 634-643.

Beutel, A., \& Marini, M. (1995). Gender and values. American Sociological Review, $60,436-448$.

Blake, J. (2007). Missing links: Gender and education for sustainable development. International Journal of Innovation and Sustainable Development, 2(3/4), 414-432.

Block, J. H. (1973). Conceptions of sex-role: some cross-cultural and longitudinal perspectives. American Psychologist, 28, 512-526.

Brougham, R. R., Zail, C. M., Mendoza, C. M., \& Miller, J. R. (2009). Stress, sex differences, and coping strategies among college students. Current Psychology, 28(2), 85-97.

Chodorow, N. (1974). Family structure and feminine perspective. In M. Rosaldo \& L. Lamphere (Eds.), Women in culture and society (pp.41-48). Stanford, CA: Stanford University Press.

Connell, R.W. (1995). Masculinities. Berkeley, CA, USA: University of California Press.

Eagly, A. (1987). Sex differences in social behaviour: A social role interpretation. Hillsdale, N. J.: Erlbaum.

Eichinger, J., Heifefetz, L. H., \& Ingraham, C. (1991). Situational shifts in social role orientation: correlates of work satisfaction and burnout among women in special education. Sex Roles, 25, 427-442.

Eisler, R. (1994). From domination to partnership: The hidden subtext for sustainable change. Journal of Organizational Change Management, 7(4), 35-49.

Eisler, A. D., Eisler, H., \& Yoshida, M. (2003). Perception of human ecology: Crosscultural and gender comparisons. Journal of Environmental Psychology, 23(1), 89-101.

Erikson, E. H. (1982). The life cycle completed. New York: Norton.

European Social Foundation. (2017). Sabiedrības izpratnes un informètības paangstināšanas pasākumu stratēẹija pretdiskriminācijas un dažādības veicināšanai [Action strategy for the development of social understanding and awareness to promote anti-discrimination and diversity]. Society Integration Foundation.

European Commission. (2009). Gender in EU-funded research. Toolkit. Retrieved from https://publications.europa.eu/en/publication-detail/-/publication/.../language-en

Fischer, J. L., \& Narus, L. R. (1981). Sex role development in late adolescence and adulthood. Sex Roles, 7(2), 97-106.

Fiske, S. T., Cuddy, A. J. C., Glick, P., \& Xu, J. (2002). A model of (often mixed) stereotype content: Competence and warmth respectively follow from perceived status and competition. Journal of Personality and Social Psychology, 82, 878-902. 
Franz-Balsen, A. (2014). Gender and (Un) sustainability - can communication solve a conflict of norms? Sustainability, 6(4), 1973-1991.

Gilligan, C. (1982). In a different voice. Cambridge, MA: Harvard University Press.

Guttman, D. (1965). Women and the conception of ego strength. Merrill Palmer Quarterly, 11, 229-240.

Heinzle, S., Kanzig, J., Nentwich, J., \& Offenberger, U. (2010). Moving beyond gender differences in research on sustainable consumption: Evidence from a discrete choice experiment. Working paper No. 6 within the project Soziale, ökologische und ökonomische Dimensionen eines nachhaltigen Energiekonsums in Wohngebäuden. Retrieved from http://kooperationen.zew.de/fileadmin/user_upload/Redaktion/ Seco@home/nachhaltiger_Energiekonsum/Werkstattberichte/Gender_Werkstatt bericht6.pdf

Hoffman, R. M., \& Borders, L. D. (2001). Twenty-five years after the Bem Sex-role Inventory: A reassessment and new issues regarding classification variability. Measurement and Evaluation in Counseling and Development, 34(1), 39-55.

Howard, J. A., \& Hollander, J. A. (1996). Gendered situations, gendered selves. Thousand Oaks, CA: Sage.

Hyde, J. S. (2005). The gender similarities hypothesis. American Psychologist, 60, 581-592.

Hyde, J. S., Krajnik, M., \& Skuldt-Niederberger, K. (1991). Androgyny across the life span: A replication and longitudinal followup. Developmental Psychology, 27, 516-519.

Hyde, J. S., \& Phillis, D. E. (1979). Androgyny across the life span. Developmental Psychology, 15(3), 334-336.

Hunt, J. (2004). Introduction to gender analysis concepts and steps. Development Bulletin, 64, 100-106.

Hunter, L. M., Hatch, A., \& Johnson, A. (2004). Cross-national gender variation in environmental behaviors. Social Science Quarterly, 85(3), 677-694.

Ivtzan, I., \& Conneely, R. (2009). Androgyny in the mirror of self-actualisation and spiritual health. The Open Psychology Journal, 2, 58-70.

Kark, R. (2017). Androgyny. In V. Zeigler-Hill \& T.K. Shackelford (Eds.), Encyclopedia of personality and individual differences. Springer International Publishing AG.

Kark, R., Waismel-Manor, R., \& Shamir, B. (2012). Does valuing androgyny and femininity lead to a female advantage? The relationship between gender-role, transformational leadership and identification. TheLeadership Quarterly, 23(3), 620-640.

Kasen, S., Chen, H., Sneed, J., Crawford, T., \& Cohen, P. (2006). Social role and birth cohort influences on gender-linked personality traits in women: A 20-year longitudinal analysis. Journal of Personality and Social Psychology, 91(5), 944-958.

Keller, E. (1985). Reflections on gender and science. New Haven, CT: Yale University Press.

Koenig, A. M., Eagly, A. H., Mitchell, A. A., \& Ristikari, T. (2011). Are leader stereotypes masculine? A meta-analysis of three research paradigms. Psychological Bulletin, 137(4), 616-642.

Leszczynski, J. P., \& Strough, J. (2008). The contextual specificity of masculinity and femininity in early adolescence. Social Development, 17, 719-736. 
Norlander, T., Erixon, A., \& Archer, T. (2000). Psychological androgyny and creativity: Dynamics of gender-role and personality trait. Social Behavior and Personality: An International Journal, 28(5), 423-435.

Olsson, D., \& Gericke, N. (2017). The effect of gender on students' sustainability consciousness: A nationwide Swedish study. The Journal of Environmental Education, 48(5), 357-370.

Parson, T., \& Bales, R. (1955). Family, socialization and interaction process. Glencoe, Ill.: Free Press.

Perry, D. G., \& Pauletti, R. E. (2011). Gender and adolescent development. Journal of Research on Adolescence, 21(1), 61-74.

Pickard, J., \& Strough, J. (2003). The effects of same-sex and other-sex contexts on masculinity and femininity. Sex Roles, 48, 421-432.

Pipere, A. (2016). Envisioning complexity: Towards a new conceptualization of educational research for sustainability. Discourse and Communication for Sustainable Education, 7(2), 68-91. doi: 10.1515/dcse-2016-0017

Rogers, R. A. (2008). Beasts, burgers and hummers: Meat and the crisis of masculinity in contemporary television advertisements. Environmental Communication, 2(3), 281-301.

Salite, I. (2015). Searching for sustainability in teacher education and educational research: Experiences from the Baltic and Black Sea Circle Consortium for educational research. Discourse and Communication for Sustainable Education, 6, 21-29. doi: 10.1515/dcse-2015-0002.

Schalkwyk, J. (2000). Culture, gender equality and development cooperation. The Canadian International Development Agency. Retrieved from www.oecd.org/social/ gender-development/1896320.pdf

Schultz, I., \& Stiess, E. (2009). WP1. Gender aspects of sustainable consumption strategies and instruments. Policies to Promote Sustainable Consumption Patterns, EUPOP. Institute for Social-Ecological Research, Frankfurt/Main.

Schwendenman, D. (2012). Gender role expectations of classroom teachers. Doctoral dissertation. The University of Dayton.

Spence, J., Helmreich, R., \& Stapp, J. (1975). Ratings of self and peers on sex role attributes and their relation to self-esteem and conceptions of masculinity and femininity. Journal of Personality and Social Psychology, 32, 29-39.

Spence, J. T. (1993).Gender-related traits and gender ideology: Evidence for a multifactorial theory. Journal of Personality and Social Psychology, 64(4), 624-635.

Spence, J. T. (1999). Thirty years of gender research: A personal chronicle. In W. Swann, L. Langlois, \& L. Gilbert (Eds.), Sexism and stereotypes in modern society. The gender science of Janet Taylor Spence (pp. 255-289). Washington, DC: American Psychological Association.

Starr, C. R., \& Zurbriggen, E. L. (2017). Sandra Bem's schema theory after 34 years: A review of its reach and impact. Sex Roles, 76, 566-578.

Stets, J. E., \& Burke, P. J. (2000). Femininity/masculinity. In E. Borgatta\& R. Montgomery (Eds.), Encyclopedia of sociology (Revised ed., pp. 997-1005). New York: MacMillan.

Strough, J. N., Leszczynski, J. P., Neely, T. L., Flinn, J. A., \& Margrett, J. (2007). From adolescence to later adulthood: Femininity, masculinity, and androgyny in six age groups. Sex Roles, 57, 385-396. 
Tobin, D. D., Menon, M., Menon, M., Spatta, B. C., Hodges, E. V. E., \& Perry, D. G. (2010). The intrapsychics of gender: A model of self-socialization. Psychological Review, 117(2), 601-622.

Twenge, J. M. (1997). Changes in masculine and feminine traits over time: A metaanalysis. Sex Roles, 36, 305-325.

Earth Charter Commission. (2000). The Earth Charter. San Jose, Costa Rica: Earth Charter International. Retrieved from http://www.earthcharter.org

UNESCO. (2014). Bonn Declaration. Retrieved from http://www.esd-world-conference2009.org/ fileadmin/download/ESD2009_BonnDeclaration080409.pdf

UNESCO. (2015). Transforming our World: The 2030 Agenda for Sustainable Development.

Unger, R., \& Crawford, M. (1996). Women and gender: A feminist psychology. New York: McGraw-Hill.

Vantieghem, W., Vermeersch, H., \& Van Houtte, M. (2014). Why “Gender” disappeared from the gender gap: (Re-) introducing gender identity theory to educational gender gap research. Social Psychology of Education: An International Journal, 17(3), 357-381.

Vinz, D. (2009). Gender and sustainable consumption: A German environmental perspective. European Journal of Women's Studies, 16(2), 159-179.

West, C., \& Zimmerman, D. H. (1987). Doing gender. Gender and Society, 1(2), 125151.

Wilkinson, S., \& Kitzinger, C. (Eds.) (1996). Representing the other: A feminist and psychology reader. Thousand Oaks, CA: Sage.

Wood, W., \& Eagly, A. H. (2002). A cross-cultural analysis of the behavior of women and men: Implications for the origins of sex differences. Psychological Bulletin, 128, 699-727.

Wood, W., \& Eagly, A. H. (2009). Gender identity. In R. H. M. Leary (Ed.), Handbook of individual differences in social behavior (pp. 109-125). New York: Guilford Press.

Wood, W., \& Eagly, A. H. (2015). Two traditions of research on gender identity. Sex Roles, 73, 461-473.

Xiao, C., \& Hong, D. (2010). Gender differences in environmental behaviors in China. Population and Environment, 32, 88-104.

Zelezny, L. C., Chua, P. P., \& Aldrich, C. (2000). Elaborating on gender differences in environmentalism. Journal of Social Issues, 56, 443-457.

Huang, X., Zhu, X.-L., Zheng, J., \& Zhan, L. (2012). Relationships among androgyny, self-esteem, and trait coping style of Chinese university students. Social Behaviour and Personality, 40(6), 1005-1014.

Cai, H., Huang X., \& Song, H. (2008). The relationship between sex role and subjective well-being in China [In Chinese]. Acta Psychologica Sinica, 40, 474-486.

Психодиагностические методики изучения гендерных особенностей личности. (2013). / Сост. Е. Д. Беспанская-Павленко. Минск: БГУ.

Correspondence concerning this paper should be addressed to Jelena Badjanova, Dr. paed., Daugavpils University, Parades street 1, Daugavpils, Latvia, LV-5401. Email: helenija@inbox.lv 